\title{
Comparative Evaluation of the Preservative Effect of Benzoate, Sulphite and Nisin on the Quality of White Layer Cake
}

\author{
Adeoye Bolade Kikelomo
}

\author{
Department Of Agriculture and Industrial Technology (Nutrition \& Dietetics Unit), Babcock University, llisan- Remo, \\ Ogun State, Nigeria. \\ Email: evangadeoye2002@gmail.com; Phone: +234-08020708806
}

\begin{abstract}
Effect of sodium benzoate $\left(\mathrm{NaC}_{6} \mathrm{H}_{5} \mathrm{CO}_{2}\right)$, sodium metabisulphite $\left(\mathrm{Na}_{2} \mathrm{~S}_{2} \mathrm{O}_{5}\right)$, and nisin as preservatives in white layer cake was studied. Cake samples of different concentrations of the preservatives were prepared by incorporating the preservatives into the cake mix separately. The concentrations incorporated were; 0.05 and $0.1 \%$ sodium benzoate, 200 and 250ppm sodium metabisulphite 200 and 250 ppm nisin, and control had no preservative. Results of microbiological analysis showed that sodium benzoate, sodium metabisulphite and nisin, all have inhibitory effect on spoilage organisms of cake however, sodium benzoate had the highest inhibitory effect against fungi. There was no marked effect on the specific volume, volume, symmetry, uniformity, chemical, physico- chemical properties and sensory attributes of the cake samples $(P<0.05)$.
\end{abstract}

Key words: cake, sodium benzoate, sodium metabisulphite, nisin

\section{INTRODUCTION}

According to Fantozzi and Sensidoni (1993), cake could be defined as an edible leavened or unleavened baked, sweet flour confectionery, often enriched with other minor compounds for appearance, it is typically round and flat in shape.

Cakes of all types rarely undergo bacterial spoilage due to their usually high concentration of sugars, which restrict the availability of water. The most common form of spoilage displayed by these products is mouldiness and common; sources of spoilage mould are any and all cake ingredients. While the baking process is generally sufficient to destroy these organisms, moulds may enter baked cakes from handling and from air. Growth of moulds on the surface of cakes is favoured by high humidity and continued growth of moulds on cakes results in a hardening of the product. In order to extend shelf life of cakes by inhibiting mould growth, chemical preservatives are often incorporated and sorbic acid, propionic acid and their salts are used in extending shelf life of cake (Jay, 1992; Bennion and Bamford, 1973). However, Arowona ( 1997) found a spice; Aframomumdanielli to have better inhibitory effect on bread spoilage organism compared to sorbic acid. Thus, the effect of other permitted preservatives need to be investigated.

Benzoate is most active against yeast and bacteria and least active against moulds. Levels of use usually range from 0.05 to 0.1 per cent by weight and it causes no deleterious effect as it is readily eliminated from the body (Lindsay, 1996).

Sodium metabisulphite on the other hand is an unusually multifunctional food additive and it application in bakery is in the production of biscuit where $200-300 p p m$ is permitted in biscuit dough in U.K. in order to produce less resilient and soft dough (Blanshard, 1986).

The stimulus for investigating nisin use in food preservation was presented in the period of the later 1940s and early 1950s when clostridal spoilage of low-acid nature cheeses became a serious problem (Fowler and Gasson 1992) and now nisin is clearly the most widely used antibiotic for food preservation with around 46 countries permitting its use in foods to varying degree (Jay, 1992). It has been used successfully in different products and in both low acid food and non acid food (Singh et. al., 1987). Nisin is naturally produce by Lactococcus Lactis and its inhibitory effect was found to be restricted to gram-prositive bacteria(Russel\& Gould, 1991) however its effect has not been demonstrated against yeast and mould (Fowler and Gasson, 1992).

\section{METHODOLOGY}

Flour was sieved to remove extraneous particles and egg white was separated from the egg yolk with the egg separator. The recipe was in accordance with AACC method (AACC, 1983) with little variation in the quantity of sugar used (Penfield \& Campbell, 1992). The recipe is as follow: Flour; 150g, Sugar; 125g, Low fat dry milk; 18g, Egg white; 
14g, Shortening; 73g, Salt; $2 \mathrm{~g}$, Water; $98 \mathrm{~g}$, leavening; $5 \mathrm{~g}$, sodium benzoate;0.05\% ( $0.24 \mathrm{~g})$, sodium benzoate; $0.1 \%($ $0.48 \mathrm{~g}$ ), sodium metabisulphite; 200ppm (0.1g), sodium metabisulphite; 250ppm (0.12g), nisin;250ppm (0.12g), nisin; 200ppm (0.1g).

The batter was prepared using sugar batter method described by Bennion and Bamford (1973). The shortening and sugar were creamed together for 10 minutes in Kenwood Chef Mixer, Model Km 200 at medium speed. Egg white was then incorporated and creamed for another 3 minutes after which the flour, leavening, preservative, milk, salt were added and gently mixed into the batter. Water was added at the same time and mixing was completed in the next 3 minutes.

$75 \mathrm{~g}$ of batter was weighed into grey coloured, round pans of $9.5 \mathrm{~cm}$ diameter and $4 \mathrm{~cm}$ height. The cakes were baked at $200^{\circ} \mathrm{C}$ and it took average of 25 minutes for each cake sample to be baked in a conventional oven.

The baked cakes were allowed to cool before packaging in high density polyethylene and were stored at room temperature $\left(27 \pm 2^{0} \mathrm{C}\right)$ for subsequent analysis.

\section{RESULTS:}

Table 1: Temperature, $\mathrm{pH}$, Specific gravity and Specific volume of different treatments of cake batter

\begin{tabular}{|l|l|l|l|l|}
\hline Treatments & $\begin{array}{l}\text { Temperature } \\
\left({ }^{\circ} \mathrm{C}\right)\end{array}$ & $\mathrm{pH}$ & $\begin{array}{l}\text { Specific } \\
\text { Gravity }\end{array}$ & $\begin{array}{l}\text { Specific } \\
\text { volume } \\
\left(\mathrm{cm}^{3} / \mathrm{g}\right)\end{array}$ \\
\hline $0.05 \%$ Benzoate & 26 & 6.2 & 0.99 & 1.11 \\
\hline $0.1 \%$ Benzoate & 26 & 6.4 & 0.96 & 1.15 \\
\hline 200 ppm Sulphite & 26 & 6.3 & 0.97 & 1.14 \\
\hline 250 ppm Sulphite & 26 & 6.3 & 0.99 & 1.11 \\
\hline $200 p p m$ Nisin & 26 & 6.3 & 0.98 & 1.12 \\
\hline $250 p p m$ Nisin & 26 & 6.3 & 0.95 & 1.16 \\
\hline Control & 26 & 6.4 & 0.98 & 1.16 \\
\hline
\end{tabular}

Table 2: Physical properties of cake samples. (Specific volume, Volume, Symmetry and Uniformity of cake samples)

\begin{tabular}{|l|l|l|l|l|}
\hline Treatments & $\begin{array}{l}\text { Specific volume } \\
\left(\mathrm{cm}^{3} / \mathrm{g}\right)\end{array}$ & $\begin{array}{l}\text { Volume } \\
\left(\mathrm{mm}^{3}\right)\end{array}$ & $\begin{array}{l}\text { Symmetry } \\
(\mathrm{mm})\end{array}$ & $\begin{array}{l}\text { Uniformity } \\
(\mathrm{mm})\end{array}$ \\
\hline $0.05 \%$ Benzoate & 1.5 & 68 & 4 & 0 \\
\hline $0.1 \%$ Benzoate & 1.6 & 67 & 5 & 0 \\
\hline $200 p p m$ Sulphite & 1.6 & 69 & 5 & 0 \\
\hline $250 \mathrm{ppm}$ Sulphite & 1.5 & 69 & 5 & 0 \\
\hline $200 p p m$ Nisin & 1.5 & 69 & 5 & 0 \\
\hline $250 p p m$ Nisin & 1.5 & 69 & 5 & 0 \\
\hline Control & 1.5 & 68 & 4 & 0 \\
\hline
\end{tabular}


Table 3: Chemical andPhysico-chemical changes in cake samples during storage

\begin{tabular}{|l|l|l|l|l|l|}
\hline \multirow{2}{*}{ Treatments } & Crust & \multicolumn{3}{l|}{$\begin{array}{l}\text { Crust } \\
\text { (\% Moisture Content) }\end{array}$} & \multicolumn{2}{l|}{$\begin{array}{l}\text { Crumb } \\
\text { (\%Moisture content) }\end{array}$} \\
\cline { 2 - 7 } & $\begin{array}{l}\text { Absorbance } \\
(420 \mathrm{~nm})\end{array}$ & $1^{\text {st }}$ day & $5^{\text {th }}$ day & $1^{\text {st }}$ day & $5^{\text {th }}$ day \\
\hline $0.05 \%$ Benzoate & 0.11 & 21 & 24 & 25 & 21 \\
\hline $0.1 \%$ Benzoate & 0.1 & 21 & 23 & 26 & 21 \\
\hline 200ppm Sulphite & 0.09 & 19 & 22 & 26 & 21 \\
\hline 250ppm Sulphite & 0.1 & 20 & 23 & 24 & 20 \\
\hline 200ppm Nisin & 0.1 & 21 & 23 & 24 & 19 \\
\hline 250ppm Nisin & 0.09 & 20 & 23 & 24 & 20 \\
\hline Control & 0.1 & 21 & 24 & 26 & 21 \\
\hline
\end{tabular}

Degree of browning measured as absorbance and rate of staling measured as relative moisture content of the crust and crumb.

Table 4: Total fugal count (cfu/ml) and Total viable count (cfu/ml) of cake samples stored at ambient temperature $\left(27 \pm 2^{\circ} \mathrm{C}\right)$ for seven days

\begin{tabular}{|l|l|l|l|l|l|l|}
\hline \multirow{2}{*}{ Treatments } & \multicolumn{2}{l|}{ Total fungal count (TFC) } & \multicolumn{2}{l|}{ Total viable count (TVC) } \\
\cline { 2 - 7 } & $1^{\text {st }}$ day & $4^{\text {th }}$ day & $7^{\text {th }}$ day & $1^{\text {st }}$ day & $4^{\text {th }}$ day & $7^{\text {th }}$ day \\
\hline $0.5 \%$ Benzoate & Nil & $5.0 \times 10^{4 \mathrm{~s}}$ & $1.0 \times 10^{5}$ & $3.0 \times 10^{6}$ & $3.1 \times 10^{6}$ & $3.2 \times 10^{6}$ \\
\hline $0.1 \%$ Benzoate & Nil & $2.5 \times 10^{3}$ & $5.0 \times 10^{4}$ & $2.5 \times 10^{6}$ & $2.7 \times 10^{6}$ & $2.9 \times 10^{6}$ \\
\hline $200 p p m$ Sulphite & Nil & $1.0 \times 10^{5}$ & $2.0 \times 10^{5}$ & $3.8 \times 10^{6}$ & $3.9 \times 10^{6}$ & $4.1 \times 10^{6}$ \\
\hline $250 \mathrm{ppm}$ Sulphite & Nil & $1.0 \times 10^{5}$ & $2.0 \times 10^{5}$ & $2.5 \times 10^{6}$ & $2.6 \times 10^{6}$ & $2.8 \times 10^{6}$ \\
\hline 200ppm Nisin & Nil & $5.0 \times 10^{4}$ & $1.0 \times 10^{5}$ & $2.3 \times 10^{6}$ & $2.4 \times 10^{6}$ & $2.5 \times 10^{6}$ \\
\hline 250ppm Nisin & Nil & $5.0 \times 10^{4}$ & $1.0 \times 10^{5}$ & $2.0 \times 10^{6}$ & $2.1 \times 10^{6}$ & $2.2 \times 10^{6}$ \\
\hline Control & $2.0 \times 10^{5}$ & $5.0 \times 10^{5}$ & $8.0 \times 10^{5}$ & $9.0 \times 10^{6}$ & $9.3 \times 10^{6}$ & $10.2 \times 10^{6}$ \\
\hline
\end{tabular}

Table 5: The Sensory means score of different treatments of cake samples.

\begin{tabular}{|l|l|l|l|l|l|}
\hline Treatments & \multicolumn{4}{l|}{ Attributes } & \multicolumn{4}{l|}{} \\
\hline & Colour & Texture & Taste & Flavour & $\begin{array}{l}\text { Overall } \\
\text { Acceptability }\end{array}$ \\
\hline $0.5 \%$ Benzoate & $5.3^{\mathrm{a}}$ & $4.8^{\mathrm{a}}$ & $4.8^{\mathrm{ab}}$ & $5.3^{\mathrm{a}}$ & $4.9^{\mathrm{a}}$ \\
\hline $0.1 \%$ Benzoate & $5.1^{\mathrm{a}}$ & $5.3^{\mathrm{a}}$ & $4.6^{\mathrm{a}}$ & $4.6^{\mathrm{a}}$ & $4.4^{\mathrm{a}}$ \\
\hline 200ppm Sulphite & $5.3^{\mathrm{a}}$ & $4.4^{\mathrm{a}}$ & $4.7^{\mathrm{a}}$ & $5.2^{\mathrm{a}}$ & $4.7^{\mathrm{a}}$ \\
\hline $250 \mathrm{ppm}$ Sulphite & $5.3^{\mathrm{a}}$ & $5.3^{\mathrm{a}}$ & $5.0^{\mathrm{a}}$ & $4.9^{\mathrm{a}}$ & $4.9^{\mathrm{a}}$ \\
\hline 200ppm Nisin & $5.6^{\mathrm{a}}$ & $5.3^{\mathrm{a}}$ & $5.3^{\mathrm{a}}$ & $5.3^{\mathrm{a}}$ & $4.3^{\mathrm{a}}$ \\
\hline 250ppm Nisin & $5.1^{\mathrm{a}}$ & $5.7^{\mathrm{a}}$ & $5.4^{\mathrm{a}}$ & $4.7^{\mathrm{a}}$ & $4.9^{\mathrm{a}}$ \\
\hline Control & $5.5^{\mathrm{a}}$ & $5.6^{\mathrm{a}}$ & $5.4^{\mathrm{a}}$ & $5.3^{\mathrm{a}}$ & $4.9^{\mathrm{a}}$ \\
\hline
\end{tabular}

Mean values with different superscripts in each of the columns differ significantly $(P<0.05)$. 


\section{DISCUSSION}

Table I show the temperature, $\mathrm{pH}$, specific gravity and specific volume of the cake batters. The measured temperature of the cake batters was the same and this nullify any varied effect on cake quality as a result of temperature difference. The little variation in the $\mathrm{pH}$ can not be attributed to the different preservatives used as there was no trend in the values. However, the $\mathrm{pH}$ values were all below the recommended $\mathrm{pH} 7.2-7.8$ for white layer cake (Pyler, 1988) and this is likely to be due to the formulation containing more of the $\mathrm{pH}$ reducing ingredients. The values of specific gravity of the batters showed that the batters have less weight than equal volume of water and values are within and close to the stipulated value (0.95-0.97) for white layer cake (Pyler, 1988). The different preservatives had no significant effect on the specific volume of the batter that ranged from 1.11 to 1.16 . This is close to the value of 1.3 reported by Bennion \& Bamford (1973).

Table 2 show the specific volume, volume, symmetry, and uniformity of cake samples. The values of specific volume varied slightly, with 1.6 been the highest and 1.5 the lowest, the values for volume ranges between 67-69, for symmetry the values ranges between 4-5 for symmetry and the value for uniformity remain zero for all the samples. When these values were compared to the values of the control it was found that the preservatives did not have significant effects on the measured parameters.

Table 3 show the absorbance readings of samples' crust and moisture content of crust and crumb on the first and fifth day as a measure of rate of staling. It was found that the moisture content of the crust increased as expected. Corsetti et. al., (1998) reported that as staling progressed; there is usually movement of water from crumb to crust. However, there was no significant difference in the moisture content of the treated samples and the control which connotes that the treatments did not have any significant effect on rate of staling of the cake samples. It was also found from the result that rate of staling of the samples was independent of initial moisture content as Kim \& Walker (1992) reported.

Table 4 show the effect of different preservatives on the microbial load of cake samples. Sodium benzoate had the greatest effect on the mould and yeast as reflected in the total fungal count. Metabisulphite had lower effect than nisin on the total fungal count which could have been as a result of the fact that $\mathrm{HSO}_{3}$ ion at high $\mathrm{pH}$ is only effective against bacteria.

From the result of the TVC, it was also found that the initial value of TVC was high in all the treated samples and the reference sample but through the seven days storage, the level increased gradually. This could be attributed to the high concentration of sugar which subsequently lowered the water activity below the optimum level for bacteria growth and the little increase in TVC was as a result of increase in TFC.

The mean sensory score of the samples were presented on Table 5. Samples were rated as been the same as the control sample in colour and this implies that the cake colour was not affected by the preservatives. The mean scores for texture of the treated samples were not significantly different $(P<0.05)$ as all samples were rated comparable to the control sample. Samples with benzoate were significantly different in taste while there was no effect on the flavour of the cake. There was no significant difference in overall acceptability.

\section{CONCLUSION}

Sodium benzoate, sodium metabisulphite and nisin all have inhibitory effect on spoilage organisms of cake with sodium benzoate being most inhibitory. More importantly, with the use of any of the three as preservative there was no deleterious effect on the quality of white layer cake.

\section{REFERENCES}

American Association of Cereal Chemists (1983) . Approved methods of the AACC Method 10-90,

Arowona, M. O. (1997). Evaluation of the spice aframomumdanielli as sorbic substitute in bread production. Unpublished thesis, Dept. of Food Technol, University of Ibadan.

Bennion, E. B. \&Bamford, G. S. T. (1973).The technology of cake making.Leonard Hills Books.

Blanshard, J. M. V., Frazier, P. J. \& Galliard, T. (1996).Chemistry and physics of baking. Special publication, No. 56. The royal society of chemistry, London.

Corsetti, A., Gobbetti, M., \&Rosi, J. (1994). Sourdough fermentation in presence of added soluble carbohydrates microbial ailments - Nutr. $12: 377-385$.

Fantozzi, P. \&Sensidoni, A. (1993).Cakes.In encyclopaedia of food sci., food tech. and nutr. Academic press. Pp. 572 -577 .

Fowler, G. G. \&Gasson, M. J.(1991). Antibiotics - nisin. In food preservatives published by avi, and imprint of Van Nostrand Reinhold NY.

Jay, J. M. (1992). Modern Food Microbiology. $4^{\text {th }}$ ed. An avi book published by Van Nostrand Reinhold, NY.

Kim, C. S. \& Walker, C. E. (1992). Interaction between starches, sugars and emulsifiers in high ratio cakes model systems. J. cereal chemistry 69: $206-212$. 
Lindsay, R. C (1996).Food additives. In Food chemistry edited by Fennema, O.R. $3^{\text {rd }}$ ed. Published by Marcel Dekkar, Inc.

Penfield, M. P \& Campbell, A. M (1992). Experimental Food Science. $3^{\text {rd }}$ edition Pp $28-31,452-470$.

Pyler, E. J. (1988). Baking science and technology, $3^{\text {rd }}$ ed., vol II.Sosland publishing co. Merriam, Kansas.

Russell, N. J. \& Gould, G. W.(1991). Food Preservatives published by avi, an imprint of Van Nostrand Reinhold NY.

Singh, L., Mohan, M. \&Sankaran, R. (1987).Nisin as an aid for thermal preservation of indian dishes - upma and kheer. J. food sci. and technol. 24:277-28 